\title{
FACTORS AFFECTING THE FREQUENCY OF CONSUMPTION OF DOMESTIC AND FOREIGN FAST FOOD BRANDS
}

\author{
Dragana M. Tomašević* ${ }^{1}$, Branislav S. Radnović ${ }^{2}$, Dragana Lj. Gašević ${ }^{1}$ \\ ${ }^{1}$ Novi Sad School of Business, 21000 Novi Sad, Vladimira Perića - Valtera 4, Serbia \\ ${ }^{2}$ Educons University, Faculty for Business Economy, 21008 Novi Sad - Sremska Kamenica, \\ Vojvode Putnika 87, Serbia
}

\begin{abstract}
The rapid pace of life in recent years has led to an increase in the consumption of fastfood in all age and social groups, and in this regard to an increase in the number of newly opened fast-food restaurants. Previously conducted research work in this field has shown that various factors influence an individual's decision (not) to consume fast-food, and the following five factors have stood out: convenience, brand reputation, quality, consistency and cost. Therefore, the aim of this research was identifying the key factors that influence the frequency of consumption of domestic and foreign fast-food brands. The sample included 146 subjects of different gender, age, qualifications, and employment status. The preliminary online research was carried out using the anonymous three-section questionnaire. Based on the data obtained through ordinal logical regression, the primary hypothesis was confirmed, as it was found that there was a statistically significant factor in the frequency of fast-food consumption, that factor being a convenience. It has been confirmed that convenience factor implies utility and time saving, the possibility of easy access to fast-food, almost $24 \mathrm{~h}$ working hours of fast-food restaurants and their relative proximity to the respondents. From the market point of view, a significant research result is that respondents gave preference to domestic versus foreign fast-food brands.
\end{abstract}

Key words: fast food, frequency of consumption, quality, brand reputation, convenience

\section{INTRODUCTION}

Today is time of busy life. Everybody is in a speed. Eating in a speed is not only a trend of young population. Many people, particularly which live in cities are in the same situation. For them days are shorter everyday than the days before were. People from all kind of business are in the same problem. Progress in all sciences, technology changes, and new kinds of industry has changed human lifestyle all over the world and especially food consumption habits. Today, for many families, especially families in large urban cities, where all members work during all day, fast food consumption is one routine thing (Saghaian and Mohammadi, 2018). Emancipation and equalization of woman's rights make a space for fast food restaurants and higher consumption of takeaway foods, too. It is evident all around the world. People have not enough time for eating as they had in earlier centuries. A specific virus of younger people named "eat in walking" caught everybody on planet. It is a big problem for people`s health, but it is a real global street situation. New generations enjoy consuming 
fast foods, especially foods like burgers, pancakes, chips, pizza, etc. Aggressive marketing of fast food services affects to children and their parents, creating addiction and obesity in children from an early age (Binkey, 2019). Their tastes are changing. Emotions are different. Consumer behaviors are changing. Today, all are in changing.

Consumption of takeaway and fast food is very interesting for business practice on one and for scientific works, on the other side. This concept of restaurants made in the USA at the beginning of 50's last century. Following the history of fast food restaurants, one of the misconceptions is that they originated in the 20's century. Generally, fast food service appeared in ancient Rome, but it can be said that in the 20's of the last century it experienced a kind of market boom and today there are many fast food chains in the world, serving different kind of meals, for example: burger - McDonald`s, Burger King; pizza - Pizza Cut; seafood - Red Lobster; chicken foods - KFC; beef steak - Sizzler; sandwich - Subway; pancake - Country Kitchen (Manap and Artykabayeva, 2020). It is very interesting that fast foods such as hamburgers, pizza, and fried chicken are used about $92 \%$ by the younger generation in Kuwait (Shaban and Alkazemi, 2019). Nowadays, it is a modern big global industry with annual revenue over 580 milliards dollars, over than 13 million employees and $2.8 \%$ annual percent of growth (Šapić, 2017).

During the last few decades, the street food sector has expanded rapidly in urban areas of low- and middle-income societies, both in terms of providing access to a diversity of inexpensive foods for low-income households and in offering job opportunities for many urban residents (Maxwell et al., 2010). Consumption of fast food is no longer confined to the developed countries; it has spread to the developing countries as well. Consumption of takeaway and fast food continues to increase worldwide, especially in Western societies and is particularly widespread among young people adolescents.

The most frequent consumers of fast foods are reported to be people in their teens and twenties (Lee, 2007). Major changes in the life styles, income levels, social structure and consumption patterns in the last decade means they are increasingly prone to eat meals and socialize over food outside of the home. The rapid increase in the number of shopping malls and hypermarkets across the countries has led to an emerging demand for the growing number of fast food chains and restaurants.

This busy unhealthy consumption is becoming increasingly popular in developing countries among student population. For example when the young enter university life, they take more control of their lifestyle, in particular food choices and practices (Colic et al., 2003) especially if they are away from home (Brevard and Ricketts, 2006; Kremmyda et al., 2008). Eating at fast food restaurants appears to be part of the normal routine during the daily lives of college students. College students eat meals at fast food restaurants 6 to 8 times on a weekly basis (Driskell et al., 2006). Therefore, it is possible to claim that foods eaten at fast-food restaurants do substantially contribute to the nutrient intakes of college students. Unfortunately, dietary intakes of most college students fail to meet recommendations for most of the food groups (Dinger and Waigandt, 1997). The typical college student diet is high in fat and sodium and low in fruits and vegetables (Dinger, 1999). In addition, a study confirmed that college men consume more high-energy and highfat foods than women (Liedman et al, 2001). Several studies have been conducted on reasons why college students prefer to eat at fast-food restaurants. These reasons include menu choices, cost, convenience (Sneed and Holdt, 1991), taste, socializing with friends, a chance to get out (Hertzler and Frary, 1996), advertisement, and location (Driskell et al., 1996). It has also been mentioned that some of the major reasons given by college men for their eating patterns are somewhat different than those of college women (Driskell et al., 2006).

The food consumption patterns and associated nutritional risks specific to university students is a key concern (Gores, 2008; El Ansari et al., 2012). In recent years, nutritional knowledge of university students and their food consumption patterns have received global attention (Jaworovska et al., 2013; El Ansari et al., 2012; Broccia et al., 2008). This problem is the similar in all population. The culture of fast food consumption has replaced the traditional meal as the loss of the family tradition of eating together trigger the popularity of fast foods among young people. The shift from healthy, homemade food to more convenient, longer lasting fast foods combined with a sedentary lifestyle 
has resulted in global fattening and related health complications (Popkin, 2001; Yadav and Krishnan, 2008). Regular eating of fast food can increase the risk of weight gain and obesity because of having a high energy density with the presence of high levels of fat and sugar in the meal, and a correspondingly low level of fiber and protein (Jaworska et al., 2013; Kremmyda et al., 2008; El Ansari et al., 2012). Today, almost the young generation is buying unhealthy fast foods causing a long term negative effect on their health as well as putting an additional economic pressure on parents as these foods are costly (El Ansari et al., 2012). Though most of the young people consume fast food as a part of social gathering, they are getting addicted due to presence of addictive ingredients used in the fast food processing (Broccia et al., 2008.) Most of the time students prefer this kind of ready to eat foods to save both time and money (due to its easy accessibility and availability) (Jaworovska et al., 2013; Kremmyda et al., 2008). Similar trends have been observed among business people and others, too, because hectic life tempo affects everybody.

Fast food restaurants are typically distinguished by several main characteristics. There is standardized menu, portions and ingredients are tightly controlled, and the food is for immediate consumption. The general view of market experts is that fast food will continue to be a dynamic category due to lower prices when compared to other food service outlets and the speed of service offered.

An interesting cross-sectional study that was carried out in 2013 among students attending in four universities of Bangladesh gave an initial idea for the present research. The aim of the the „Bangladesh" study was to examine the preference, prevalence and pattern of fast food consumption among the students. Data from this study showed that prevalence of fast food consumption among the students was $98.5 \%$, and $43.3 \%$ of their pocket money was spent on its purchase. Moreover, the study identified the most important factors for the preference of fast food which included different factors such as good taste, easy accessibility, increased convenience and costs of meals (Bipasha and Goon, 2013). Another interesting study conducted in 2018 concluded that the main orientation of a fast food retailer should be on the cleanliness and courtesy of employees, which ultimately affects the perception that the consumer develops regarding health, which is characterristic of product quality (Morano, 2018).

One study conducted by Iran adults showed that price is a primary and most critical factor of motivation of food choice for low-level status people (Mohajeri, 2019).

Very interesting study regarding children and brands said that children generally choose products according to taste, regardless of the brand. Children use food brands to label products, which they like primarily to taste (Hemar-Nicolas, 2015). The results of another new study showed that brand hatred is fuelled by five main things, such as: negative experience from the past, poor quality of interaction, symbolic incomprehensibility, ideological incompatibility and rumours, as the biggest driver of brand hatred (Hashim, 2019).

The aim of the present study was to examine the factors which have influence on consumers' frequency in buying domestic and international brands of fast food among people of different age, social status, education, profession... The aim of this research is to explore consumers' overall behavior toward fast food chains. More specifically, the purpose here is to identify the key factors that influence the consumers' frequency of buying local or international brands of fast food restaurants. In this research we analysed five dominant factors that have impact on consumers: brand name, reputation, cost, convenience, consistency and quality. It is known that these five factors are significantly related to several demographic variables such as age, gender, income level.

\section{MATERIALS AND METHODS}

\section{Aim and hypothesis of research}

The main goal of this study is to identify factors and determine whether there is a statistically significant impact of the frequency of fast food consumption. Bering this in mind, the primary hypothesis of this paper was put forward: convenience, brand reputation, quality, consistency and cost have a significant impact on the frequency of consumption of domestic and foreign fast-food brands. Based on general hypothesis, the following special hypotheses were derived.

- H1: Convenience has a significant impact on the frequency of consumption of domestic and foreign fast-food brands 
- H2: Brand reputation has a significant impact on the frequency of consumption of domestic and foreign fast-food brands

- H3: Quality has a significant impact on the frequency of consumption of domestic and foreign fast-food brands

- H4: Consistency has a significant impact on the frequency of consumption of domestic and foreign fast-food brands

- H5: Cost has a significant impact on the frequency of consumption of domestic and foreign fast-food brands

\section{Description of the sample}

A simple random sample comprised 146 subjects. In the observed sample, there is a significantly higher percentage of male $(76.7 \%)$ compared to the female population (23.3\%). Regarding the age, the most represented category comprised respondents aged 31-40 years $(55.5 \%)$, followed by respondents aged 41-50 years (21.2\%), while a significantly smaller percentage of respondents is under 30 years, as well as respondents belonging to the age category over 50. In terms of education, respondents with a master or doctoral degree $(38.4 \%)$, a college degree (15\%) and a university degree $(38 \%)$ are most present, while $37 \%$ have a secondary education. If we take into account the employment status, the highest percentage of respondents is employed (82.2\%), with significantly lower percentage of secondary school students, students and the unemployed.

\section{Procedure and statistical data processing}

The empirical research was conducted through a questionnaire distributed to the respondents electronically in the period 19. 02. - 4. 03 . 2020. The questionnaire was structured in several sections, and the used statements were adapted from previous questionnaires examining the attitudes and preferences of consumers concerning domestic and foreign fast-food brands. The first part of the questionnaire relates to the sociodemographic characterristics of the respondents such as gender, age, marital status, employment status, qualifycations. The second part provides information on the frequency of fast-food consumption, the preference for local or foreign brands, and whether fast-food is consumed as a meal or as a snack. The third part of the survey covers 21 statements that relate to consumer attitudes about fast-food consumption, adapted from relevant literature (Ergin and Akbay, 2012). The level of agreement with the given statements was measured using a five-point Likert scale, where 1 indicates that the respondent absolutely disagrees and 5 indicates that the respondent agrees completely with the given statement.

The data collected were analysed via the SPSS statistic package. The given statements were grouped into 5 factors (convenience, brand reputation, quality, consistency and cost), and the reliability and consistency of the given statements were tested using the Cronbach's alpha coefficient. The degree of linear dependence between the above variables is shown via a correlation matrix. Subsequently, statistical significance of the influence of these five factors (independent variable) on the frequency of fast-food consumption (dependent variable) was tested by ordinal logistic regression.

Convenience refers to statements that indicate the ease and proximity of getting to fast-food, saving time, speed of preparation, as well as the fact that most fast-food restaurants are open until late at night. Consumers who use fast food meal stated that fast food saves a lot of time for them since they are always in a hurry, with a lack of time.

Taste used to be the traditional element to influence consumers' eating choices (Glanz et al., 1998). With the fundamental changes in the lifestyles, the emphasis on convenience has greatly increased. Today, consumers prefer fast food restaurants due to their easy to access locations, speed of service and more flexibility.

The brand reputation is described through statements that indicate the importance of owning a recognizable brand in the food industry, which is associated with greater reliability and quality of fast-food, which can ultimately have a positive effect on consumption itself.

This factor indicates that consumers place an emphasis on the brand name and its associations. For many respondents, popular, strong, global brands of fast food restaurants were favoured more in certain aspects such as quality, and trust. At the beginning of this research, it was evident that strong brand name recognition is a major advantage for fast food restaurants.

Costs indicate that fast-food is a cheaper option over alternative food, offering good value for 
money, and having promotions such as "take two meals at the price of one", can also have a positive effect on consumption. For consumers, primarily students or people on a limited budget, the cost of a meal are an important factor that influences their fast food restaurant preference. Going out for cheap eats is an obvious way for young consumers or consumers on limited budget and/or time to keep their spending in check. That is why fast food restaurants are seen as a good investment from their perspective. Those restaurants that provide bigger and better options at low prices are considered as attractive alternatives. Consistency applies to standard, consistent menus served at fast-food restaurants with standard flavours as well as consistent service ability.

Consistency is "formula for their products" which is a primary attribute of global fast food. That formula is expressed as the ingredients used, the assembly line created to put those ingredients together and the training given to the individuals to work on the assembly line. The availability of standardized menus, fast and courteous service in different locations of global branded fast food chain restaurants signifies consistency for the consumers. No matter what part of the world they travel, they are familiar with the fast, reliable and efficient service and the type of food that is offered at these fast food outlets. Service consistency is an expectation of all customers at all times; they want peace of mind and no unpleasant surprises.

Quality refers to statements that indicate that global brands are of higher quality, more reliable, and use high-quality ingredients to prepare their meals. The operations of global fast food chains follow a host of dietary and marketing rules set by various governments and culture of societies around the world. Consumers seem to possess this information and it affects their fast food restaurant preferences. Consumers believe that these global brands have higher quality standards, participate more in research, use high quality ingredients (in products) and work more on delivering healthier and useful meals.

Moreover, it is observed that these five factors are significantly related to several demographic variables such as age, gender, income level. It was explored the influence of five factors (convenience, brand name reputation, cost, con- sistency and quality) on consumers' frequency of buying fast food.

\section{RESULTS AND DISCUSSION}

In terms of frequency of fast-food consumption (Table 1), the highest percentage of respondents in the sample consumed fast-food 2-4 times a month $(45.9 \%)$, once a month $(26.7 \%), 5-10$ times a month $(23.3 \%)$, while significantly a small percentage of respondents consume fastfood more than ten times a month $(4.1 \%)$. However, respondents in this sample when choosing to eat outside their homes prefer other service restaurants over fast-food restaurants. However, when they decide to consume fast-food, it serves most of the respondents as a meal, much less as a snack. With regard to domestic and foreign fast-food brands, the respondents' attitude is that they prefer domestic brands over foreign brands. This is supported by the fact that the largest number of respondents in the sample belonged to age category of 31-40 years and that generally the highest percentage of respondents live in the marital community $(65.1 \%)$.

The Cronbach's alpha coefficient values ranged from 0.72 to 0.86 , which indicates the adequate reliability and consistency of the statements these factors were formed. The acceptable value of the coefficient is considered to be greater than 0.7 (Nunnaly, 1978).

Before conducting the regression, the correlation between the five independent variables was examined. It was concluded that the correlation between the observed variables is statistically significant, while the Pearson coefficient value indicated that there was a moderately positive correlation $(0.465-0.682)$ between all the observed variables, which can be seen in the following table.

The results of descriptive statistics indicate that the most favourable attitude of the respondents is related to the statement that fast-food is easy to reach $(M=4.18)$, while the lowest score was recorded with the statement that a popular branded restaurant has a positive effect on the consumption ( $\mathrm{M}=2.27)$.

The largest discrepancy in the answers of the respondents was observed in the statement that they prefer not to eat unknown fast-food brands, while the greatest agreement among the respondents was found in the statement that good value for money was offered. 
Table 1.

Average monthly frequency of fast food consumption

\begin{tabular}{lcc}
\hline & Frequency & Percent \\
\hline Once a month & 39 & 26.7 \\
$2-4$ times a month & 67 & 45.9 \\
$5-10$ times a month & 34 & 23.3 \\
More than 10 times a month & 6 & 4.1 \\
\hline
\end{tabular}

Reliability and consistency of the claims were measured using Cronbach's alpha coefficient as shown in the following table (Table 2).

Table 2.

Coefficient Cronbach's alpha

\begin{tabular}{lc}
\hline & Cronbach's alpha \\
\hline Convenience & 0.796 \\
Brand name reputation & 0.776 \\
Cost & 0.726 \\
Consistency & 0.828 \\
Quality & 0.864 \\
\hline
\end{tabular}

To test the primary hypothesis stating that convenience, brand reputation, cost, consistency, and quality influence the frequency of fast-food consumption, logistic ordinal regression was applied. For the purposes of data processing in this way, all of the following elements were included in the model as independent predictors: convenience, brand reputation, costs, consistency and quality of the brand, while the categorical variable - average monthly fast-food consumption, was taken as the dependent variable. In order to test the basic assumption on which all regression models are based, multicollinearity was tested based on the Spearman's rank. The obtained results showed that there was a moderate correlation between almost all independent predictors and their value did not exceed the orientation threshold of 0.6. In order to perform additional verification of the absence of multicollinearity, the VIF (Variance Impact Factor) indicator was used. Most authors believe that this assumption is not violated unless the value of the VIF indicator is greater than 10 (Radović-Marković and Hanić, 2018). The results displayed in Table 4 indicated that multicollinearity was not present, so all the above independent predictor variables were retained in the planned model.

Before making the interpretation of the results of the regression model, it was necessary to examine whether all assumptions about the adequacy of the model were fulfilled. In other words, it was necessary to check whether the assumed predictor variable improves the prediction of the final result, i.e. it was necessary to analyse the credibility indicators.

Table 3.

Correlations between factors

\begin{tabular}{|c|c|c|c|c|c|c|}
\hline & Convenience & $\begin{array}{c}\text { Brand name } \\
\text { reputation }\end{array}$ & Cost & Consistency & Quality & \\
\hline \multirow[t]{3}{*}{ Convenience } & $\begin{array}{c}\text { Pearson } \\
\text { Correlation }\end{array}$ & 1 & $.682^{* *}$ & $.509^{* * *}$ & $.465^{* *}$ & $.476^{* * *}$ \\
\hline & Sig. (2-tailed) & & .000 & .000 & .000 & .000 \\
\hline & $\mathrm{N}$ & 146 & 146 & 146 & 146 & 146 \\
\hline \multirow[t]{3}{*}{$\begin{array}{l}\text { Brand name } \\
\text { reputation }\end{array}$} & $\begin{array}{c}\text { Pearson } \\
\text { Correlation }\end{array}$ & $.682^{* * *}$ & 1 & $.518^{* * *}$ & $.686^{* *}$ & $.716^{* * *}$ \\
\hline & Sig. (2-tailed) & .000 & & .000 & .000 & .000 \\
\hline & $\mathrm{N}$ & 146 & 146 & 146 & 146 & 146 \\
\hline \multirow[t]{3}{*}{ Cost } & $\begin{array}{c}\text { Pearson } \\
\text { Correlation }\end{array}$ & $.509^{* *}$ & $.518^{* *}$ & 1 & $.474^{* *}$ & $.524^{* *}$ \\
\hline & Sig. (2-tailed) & .000 & .000 & & .000 & .000 \\
\hline & $\mathrm{N}$ & 146 & 146 & 146 & 146 & 146 \\
\hline \multirow[t]{3}{*}{ Consistency } & $\begin{array}{c}\text { Pearson } \\
\text { Correlation }\end{array}$ & $.465^{* *}$ & $.686^{* *}$ & $.474^{* *}$ & 1 & $.669^{* *}$ \\
\hline & Sig. (2-tailed) & .000 & .000 & .000 & & .000 \\
\hline & $\mathrm{N}$ & 146 & 146 & 146 & 146 & 146 \\
\hline \multirow[t]{3}{*}{ Quality } & $\begin{array}{c}\text { Pearson } \\
\text { Correlation }\end{array}$ & $.476^{* *}$ & $.716^{* *}$ & $.524^{* * *}$ & $.669^{* * *}$ & 1 \\
\hline & Sig. (2-tailed) & .000 & .000 & .000 & .000 & \\
\hline & $\mathrm{N}$ & 146 & 146 & 146 & 146 & 146 \\
\hline
\end{tabular}

${ }^{* *}$ Correlation is significant at the 0.01 level (2-tailed) 
Based on the model filing results $\left(\chi^{2}(5\right.$, $\mathrm{n}=146)=31.194, \mathrm{p}=0.000)$, it was concluded that the statistical significance of the model was present and the model could be defined as good because it made a statistically significant contribution to the prediction of average monthly fast-food consumption (Table 5).

Table 4.

Results of multicollinearity test

\begin{tabular}{lcc}
\hline Model & Tolerance & VIF \\
\hline Convenience & .603 & 1.657 \\
Brand name & .363 & 2.758 \\
reputation & & \\
Cost & .628 & 1.593 \\
Consistency & .457 & 2.190 \\
Quality & .398 & 2.511 \\
\hline
\end{tabular}

The Goodness-of-Fit statistics showed how well the model fits in with the data. The result of this test needs not to be statistically significant to confirm the good fit of the model. Based on the results presented in the table, the Pearson test $(\chi 2(427, \mathrm{n}=146)=443.274 ; \mathrm{p}=0.283)$ and the deviation test $(\chi 2(427, \mathrm{n}=146)=313.539 ; \mathrm{p}=$ 1.000) showed that the result was not statistically significant i.e. that the model was satisfactory (Table 6). The next assumption was to examine the utility of the model by the value of the coefficient of determination (pseudo $\mathrm{r}^{2}$ ), which shown what part of the variance of the dependent variable (average monthly fast-food consumption) explained the model. As most researchers recommend the Nigel Kirk's coefficient of determination, we concluded that a set of independent predictors explained $21.2 \%$ of the variance of the dependent variable (Table 6). However, the stated value of the pseudo coefficient of determination should be interpreted with caution and most authors believe that there are no clear guidelines as to how this coefficient should be used and interpreted (Osborne, 2015; Pituch and Stevens, 2016). In addition to all the above assumptions regarding the adequacy of the model, the result of the parallel lines test had to be analyzed. Specifically, the slope coefficients in the model should be the same for all categories of criterion variables in order to determine whether there is a proportional chance of the effects of predictor variables on each category of the dependent variable. The results should be in the parallel plane for each category of the dependent variable in order to meet the assumption of parallelism in the model. The result of the parallel line test in the Table 8 should not be statistically significant, as evidenced by this result $(\chi 2(10, \mathrm{n}=146)=12.947 ; \mathrm{p}=0.227)$ and thus the process of confirming the adequacy of the model was fully completed (Table 8). When analysing the final model, it can be seen that the statistical significance of only one of the five defined predictor variables was determined. It is a predictor of convenience that has proven to be a significant explanatory variable. The obtained results imply that it is likely that the average monthly fast-food consumption will increase if some of the convenience elements are upgraded and raised to a higher level (Table 9). Based on the collected data and hypotheses, it was concluded that the convenience factor in the model had a statistically significant impact on the frequency of consumption of domestic and foreign fast food brands. In this way, the special hypothesis H1 was confirmed. These results confirm the findings of studies conducted by Ergin and Akbay (2012) and Bryant and Dundes (2008). The remaining special hypotheses $(\mathrm{H} 2$, $\mathrm{H} 3, \mathrm{H} 4$ and H5) were rejected and these factors have no statistical significance in the observed sample. The results of this research, seen especially from the aspect of convenience factor for which a positive impact has been proven, can be equated with some earlier results of similar research which showed that both foreign and domestic fast food restaurants have diversity which can certainly be classified as beneficial as positively impacts on consumers and their intentions regarding the purchase of fast food products (Šapić et al., 2019). The convenience factor can be observed through various important determinants such as: time of obtaining fast food service, ease of availability and proximity of fast food service, responsiveness or speed of delivery, etc. Generally it can be said that the fast foodservice was rated positively from the aspect of convenience factor.

Responsiveness as part of convenience was significant dimension of perceived service quality in a study conducted in China (Qin, 2010). The similarity of the results of this research and the study of Šapić et al. (2019) is also in the effect of tradition which is more pronounced in Serbia, and here it is confirmed by the fact that respondents prefer domestic fast food brands to foreign ones. Interestingly, the findings of this research, in the part that indicates the preference of domestic Serbian fast food brands are in contrast to the results obtained in India, where Indians showed greater preference for global 
fast food chains compared to their Indian domestic ones. Loyalty to world brands is greater than the Indian brand, because for them, a foreign brand means better quality (Srivastava, 2015). The reason for this is better quality which did not manifest itself as a significant factor in this study. In addition to the brand, this research did not show consistency, price and quality as significant factors influencing the consumption of fast food. The reason for this can be found in the socio-demographic and economic characteristics of the sample.

In general, nowadays, all factors analyzed here are very important for fast food consumption, but the convenience factor rises in importance to the top, because of the pace of life and work, as well as in connection with the limited time constraints, especially in the middle employed population. In this connection, the results obtained in this study are reasonable. In other different segments, perhaps other factors analyzed here would show greater significance, but here, primarily due to the characteristics of the sample itself, they were not.

Regarding the limitations of this research, exactly one of the limitations can be found in the sample structure. With a different sample, both, in qualitative terms (socio-demographic characteristics, example high involvement of the younger population-students) and in quantitative terms (breadth of coverage), the research results would certainly be different. In that sense, it could certainly be expected that some other factor, such as the price of fast food service (for example, a larger number of young unemployed students) would gain greater importance and would show as a factor of significance as in study conducted by Iranian adults (Mohajeri,
2019). If the sample included a large number of middle-aged business men with a cosmopolitan orientation, it would be expected that the brand factor and the quality factor would prove to be significant. Thus, a randomly selected sample and its socio-demographic characteristics are one main limitation of this research.

Further research could be oriented in the following directions: to examine which of these factors shows the greatest significance in certain market segments, given their different sociodemographic and economic characteristics.

Table 5.

Model fitting information

\begin{tabular}{lcccc}
\hline Model & $\begin{array}{c}\mathbf{- 2 ~ L o g} \\
\text { Likelihood }\end{array}$ & Chi-Square & df & Sig. \\
\hline $\begin{array}{l}\text { Intercept } \\
\text { only }\end{array}$ & 344.733 & & & \\
Final & 313.539 & 31.194 & 5 & .000 \\
\hline
\end{tabular}

Table 6.

Goodness-of-Fit

\begin{tabular}{lccc}
\hline & Chi-Square & df & Sig. \\
\hline Pearson & 443.274 & 427 & .283 \\
Deviance & 313.539 & 427 & 1.000 \\
\hline
\end{tabular}

Table 7.

Pseudo $\mathrm{R}^{2}$

\begin{tabular}{ll}
\hline Cox and Snell & .192 \\
\hline Nagelkerke & .212 \\
McFadden & .090 \\
\hline
\end{tabular}

Table 8.

Test of Parallel Lines*

\begin{tabular}{|c|c|c|c|c|}
\hline Model & $\begin{array}{c}2 \text { Log } \\
\text { Likelihood } \\
\end{array}$ & $\begin{array}{c}\text { Chi- } \\
\text { Square }\end{array}$ & df & $\begin{array}{c}\text { Sig } \\
.\end{array}$ \\
\hline $\begin{array}{l}\text { Null } \\
\text { Hypothesis }\end{array}$ & 313.539 & & & \\
\hline General & 300.592 & 12.947 & 10 & .227 \\
\hline
\end{tabular}

Table 9.

Parameter estimates

\begin{tabular}{|c|c|c|c|c|c|c|c|c|}
\hline & & \multirow{2}{*}{$\begin{array}{l}\text { Esti- } \\
\text { mate }\end{array}$} & \multirow[b]{2}{*}{$\begin{array}{c}\text { Std. } \\
\text { Error }\end{array}$} & \multirow[b]{2}{*}{ Wald } & \multirow[b]{2}{*}{ df } & \multirow[b]{2}{*}{ Sig. } & \multicolumn{2}{|c|}{$95 \%$ confidence interval } \\
\hline & & & & & & & $\begin{array}{l}\text { Lower } \\
\text { Bound }\end{array}$ & $\begin{array}{l}\text { Upper } \\
\text { Bound }\end{array}$ \\
\hline \multirow[t]{3}{*}{ Threshold } & $\begin{array}{l}\text { [Average monthly } \\
\text { consumption=1] }\end{array}$ & 2.006 & .720 & 7.769 & 1 & .005 & .596 & 3.417 \\
\hline & $\begin{array}{l}\text { [Average monthly } \\
\text { consumption = 2] }\end{array}$ & 4.362 & .797 & 29.927 & 1 & .000 & 2.799 & 5.924 \\
\hline & $\begin{array}{l}\text { [Average monthly } \\
\text { consumption }=3 \text { ] }\end{array}$ & 6.686 & .916 & 53.292 & 1 & .000 & 4.891 & 8.481 \\
\hline \multirow[t]{5}{*}{ Location } & Convenience & .999 & .246 & 16.446 & 1 & .000 & .516 & 1.482 \\
\hline & Brand name reputation & .047 & .287 & .027 & 1 & .870 & -.516 & .610 \\
\hline & Cost & .311 & .228 & 1.864 & 1 & .172 & -.135 & .757 \\
\hline & Consistency & -.067 & .252 & .070 & 1 & .791 & -.560 & .427 \\
\hline & Quality & -.318 & .245 & 1.682 & 1 & .195 & -.799 & .163 \\
\hline
\end{tabular}


Also, it would be interesting to investigate how certain crisis situations (such as the coronavirus pandemic) affect the greater influence of certain factors in relation to regular life and business situations. Comparative analyses among Balkan and some European developed countries could contribute to observing differences in the significance of each individual factor and to precisely determine the exactly basis of differences (economies, cultures, personal status, eating habits...).

\section{CONCLUSIONS}

Results of this study reveal the dominant factors that consumers consider as critical when they compare various fast food brands and make a final purchase decision of buying or not buying fast food. The aim of this paper was to examine consumers' attitudes about fast-food, as well as to identify key factors that influence the frequency of fast-food consumption. The survey included 146 subjects who answered questions from a questionnaire distributed in electronic form. The majority of the sample consisted of women, the middle aged and a significant number of highly educated respondents. Respondents favored other service restaurants over fast-food restaurants. However, according to the frequency of consumption, it was concluded that respondents also consumed fast-food significantly. Also, the results of the research showed that domestic brands were favored over foreign fast-food brands. Based on the responses to the 21 statements designed to examine consumers' attitudes to fast-food, 5 factors (independent variables) were identified, namely convenience, brand reputation, consistency, cost and quality. These independent variables were included in this study based on the results of previous studies. The effect of these factors on the frequency of fast-food consumption was examined by ordinal logistic regression. The results confirmed the primary hypothesis of this research that there are factors that influence the consumption of fast-food, with the convenience factor proving to be statistically significant. Given the sociodemographic characteristics of the majority of respondents (women, middle-aged, highly educated) in a randomly selected sample, it was expected that the factor of convenience would have a significant impact. Namely, several differences that make up the convenience factor: the time of availability of fast food services, the speed of obtaining fast food services, ease and availability of fast food services, etc. are extremely important for employed highly educated women with lack of free time due to large work and family obligation.

\section{REFERENCES}

Akbay, C., Tiryaki, Y. G., \& Aykut G. (2007). Consumer characteristics influencing fast food consumption in Turkey. Food Control, 18(8), 904-913.

Binkey, S. (2019). Fast-food marketing and children's fast-food consumption: a trigger to children obesity. Indian Journal of Public Health Research \& Development, 10(7), 173-177.

Bipasha, M. S., \& Goon, S. (2013). Fast food preferences and food habits among students of private universities in Bangladesh. South East Asia Journal of Public Health, 3(1), 61-64.

Brevard, P. B, \& Ricketts, C. D. (1996). Residence of college students affects dietary intake, physical activity, and serum lipid levels. Journal of the Ame-rican Dietetic Association, 96(1), 35-38.

Broccia, F., Lantini, T., Luciani, A., \& Carcassi, A., M. (2008). Nutrition knowledge of Sardinian and Corsican university students. Annali di Igiene: Medicina Preventiva e di Comunita, 20(1), 49-55.

Bryant, R., \& Dundes, L. (2008). Fast food perceptions: A pilot study of college students in Spain and the United State. Appetite, 51, 327-330.

Colic-Baric, I., Satalic, Z., \& Lukesic, Z. (2003). Nutritive value of meals, dietary habits and nutritive status in Croatian university students according to gender. International Journal of Food Science and Nutrition, 54, 473-484.

Dinger, M. K, \& Waigandt, A. (1997). Dietary intake and physical activity behaviors of male and female college students. American Journal of Health Promotion, 11, 360-362.

Dinger, M. K. (1999). Physical activity and dietary intake among college students. American Journal of Health Studies, 15, 139-149.

Driskell, J. A., Meckna, B. R., \& Scales, N. E. (2006). Differences exist in the eating habits of university men and women at fast-food restaurants. Nutrition Research, 26, 524-530.

El Ansari, W., Stock, C., \& Mikolajczyk, R. T. (2012). Relationships between food consumption and living arrangements among university students in four Euro-pean countries - a cross-sectional study. Nutrition Journal, 11, 28.

Ergin, E. A., \& Akbay, H. Ö. (2012). Factors influen-cing young consumers' preferences of domestic and international fast food brands. In Proceedings of the $11^{\text {th }}$ International Marketing Trends Conference (pp. 19-21). Venice, Austria.

Glanz, K., Basil, M., \& Mailbach, E. (1998). Why Americans eat what they do: taste, nutrition, cost, 
convenience and weight control concerns as influen-ces on food consumption. Journal of the American Dietetic Association, 98(10), 1118-1126.

Gores, S.E. (2008). Addressing nutritional issues in the college-aged client: strategies for the nurse practitioner. Journal of the American Academy of Nurse Practitioners, 20, 5 -10.

Hashim, S., \& Kasana, S. (2019). Antecedents of brand hate in the fast food industry. Spanish Journal of Marketing - ESIC, 23(2), 227-248.

Hemar-Nicolas, V., Gollety, M., Damay, C., \& Ezan, P. (2015). What brand do you eat? The influence of food brands within children's peer groups. Young Con-sumers, 16(3) 316-331.

Hertzler, A. A., \& Frary, R. B. (1996). Family factors and fat consumption of college students. Journal of the American Dietetic Association, 96(7), 711-714.

Jaworowska, A., Blackham, T., Davies G., \& Stevenson, L. (2013). Nutritional challenges and health implica-tions of takeaway and fast food. Nutrition Reviews, 71(5), 310-318.

Kremmyda, L. S., Papadaki, A., Hondros, G., Kapsokefalou, M., \& Scott J. A. (2008). Differentiating between the effect of rapid dietary acculturation and the effect of living away from home for the first time, on the diets of Greek students studying in Glasgow. Appetite, 50(2-3), 455-463.

Lee, J. S. (2007). A comparative study on fast food consumption patterns classified by age in Busan. Korean Journal of Community Nutrition, 12, 534544.

Liedman, M., Cameron, B. A., Carson, D. K., Brown, D. M., \& Meyer, S. S. (2001). Dietary fat reduction behaviors in college students: relationship to dieting status, gender and key psychosocial variables. Appetite, 36, 51-56.

Manap, A., \& Artykabayeva, A. (2020). Analysis of the fast food market in Kazakhstan. Research Result, Business and Services Technologies, 6(1), 55-64.

Maxwell, D., Levin, C., Amar-Klemesu, M., Ruel, M., Morris, S., \& Ahiadekeet, C. (2000) Urban livelihood and food and nutrition security in Greater Accra. International Food Policy Research Institute Report, 112, 11-18.

Mohajeri, M., Hoojeghani, S., Izadi, A., Ghahremanzadeh, M., Pourfarzi, F., Nemati, A., \& Barzegar, A. (2019). Food choice motivations among Ardabil - Iran adults. Nutrition \& Food Science, 50(4), 641652 .
Morano, R. S., Barrichello, A., Jacomossi, R. R., \& D'Acosta -Rivera, J. R. (2018). Street food: factors influencing perception of product quality. RAUSP Management Journal, 53(4), 535-554.

Nunnaly, J.C. (1978). Introduction to psychological measurement. New York: McGraw-Hill.

Osborne, J. W. (2015). Best practices in logistic regression. Los Angeles: Sage.

Qin, H., Prybutok, V. R, Zhao, Q. (2010). Perceived service quality in fast-food restaurants: empirical evidence from China. International Journal of Quality \& Reliability Management, 27(4), 424-437.

Pituch, K. A., \& Stevens, J. A. (2016). Applied multivariate statistics for the social science $\left(6^{\text {th }}\right.$ ed.). New York: Routledge.

Popkin, B. (2001). The nutrition transition and obesity in the developing world. Journal of Nutrition, 131(3), 871-873.

Radović-Marković, M., \& Hanić, H. (2018). Metodologija istraživanja u ekonomskim naukama. Beograd: Beogradska bankarska akademija, Fakultet za bankarstvo, osiguranje i finansije, Institut ekonomskih nauka.

Saghaian, S., \& Mohammadi, H. (2018). Affecting frequency of fast food consumption. Journal of Food Distribution Research, 49(1), 22-29.

Shaban, L., \& Alkazemi, D. (2019). Trends in fast -food consumption among Kuwaiti youth. International Journal of Preventive Medicine, 10(1), 44.

Sneed, J., \& Holdt, C. S. (1991). Many factors influence college students' eating patterns. Journal of American Dietetic Association, 91, 1380.

Srivastava, R. K. (2015). How differing demographic factors impact consumers' loyalty towards national or international fast food chains: A comparative study in emerging markets. British Food Journal, 117(4), 1354-1376.

Šapić, S. (2017). Uticaj kosmopolitizma i tradicije na procene i namere korisnika usluga brze hrane. Ekonomski horizonti, 19(2), 81-93.

Šapić, S., Filipović, J., \& Dlačić, J. (2019). Consumption in fast-food restaurants in Croatia and Serbia. British Food Journal, 121(8), 1715-1729.

Yadav, K., \& Krishnan, A. (2008). National Prevalence of Obesity: Changing patterns of diet, physical activity and obesity among urban, rural and slum populations in north India. Obesity Reviews, 9(5), 400-408. 


\title{
ФАКТОРИ КОЈИ УТИЧУ НА УЧЕСТАЛОСТ ПОТРОШЊЕ ДОМАЋИХ И ИНОСТРАНИХ БРЕНДОВА БРЗЕ ХРАНЕ
}

\author{
Драгана М. Томашевић*¹, Бранислав С. Радновић ${ }^{2}$, Драгана Љ. Гашевић $^{1}$ \\ ${ }^{1}$ Висока пословна школа струковних студија, 21000 Нови Сад, Владимира Перића - Валтера, бр. 4, \\ Србија \\ ${ }^{2}$ Универзитет Едуконс, Факултет пословне економије, 21008 Нови Сад - Сремска Каменица, \\ Војводе Путника, бр. 87, Србија
}

Сажетак: Брз темпо живота последњих година довео је до повећане конзумације брзе хране у свим животним узрастима и социјалним групама, као и с тим у вези до повећања броја новоотворених ресторана брзе хране. Претходно анализирана истраживања из ове области показују да разни фактори утичу на одлуку појединца о (не)конзумирању брзе хране, при чему се издвајају следећих 5 фактора: погодност, репутација бренда, квалитет, доследност и трошкови. Стога је циљ овог истраживања био да се идентификује који су то кључни фактори који утичу на учесталост потрошње домаћих и иностраних брендова брзе хране. Узорком је било обухваћено 146 испитаника различитог пола, старости, стручне спреме, радног статуса. Путем анонимног упитника, структурираног из три целине, онлајн путем је извршено примарно истраживање. На основу добијених података путем ординарне логичке регресије потврђена је полазна хипотеза, јер је утврђено да постоји статистички сигнификантан фактор учесталости потрошње брзе хране, а тај фактор је погодност. Потврђено је да се под фактором погодност подразумева практичност и уштеда времена, могућност да се до брзе хране лако дође, радно време ресторана брзе хране скоро 24 часа и њихова релативна близина испитаницима. Са аспекта тржишта, значајан је резултат истраживања да испитаници предност дају домаћим у односу на иностране брендове брзе хране.

Кључне речи: брза храна, учесталост потрошње, квалитет, репутација бренда, погодност

Received: 4 April 2020 / Received in revised form: 7 July 2020 / Accepted: 27 July 2020

Available online: November 2020

This is an open-access article under the CC BY license (http://creativecommons.org/licenses/by/3.0). 